

\title{
GROWTH PERFORMANCE AND INTESTINAL MICROFLORA POPULATION OF BROILERS FED AGED BROWN RICE*
}

\author{
Chia-Hung Shih ${ }^{1,2}$, Tzu-Tai Lee ${ }^{3}$, Warren Hwa-Jen $\mathrm{Kuo}^{1}, \mathrm{Bi} \mathrm{Yu}^{3 *}$ \\ ${ }^{1}$ Department of Agronomy, National Taiwan University, Taiwan \\ ${ }^{2}$ Miaoli District Agricultural Research and Extension Station, Council of Agriculture, Executive Yuan, \\ Taiwan \\ ${ }^{3}$ Department of Animal Science, National Chung Hsing University, Taiwan \\ •Corresponding author: byu@dragon.nchu.edu.tw
}

\begin{abstract}
The purpose of this study was to evaluate the growth performance and intestinal microflora population of broilers fed diets with aged brown rice (ABR) that had been stored for 3 years. The ABR was the material chosen to analyse the grain quality, which included the physical properties as well as nutrient analysis to evaluate its applicability in broiler diet. The germination rate, pH value, whiteness value of grains and fatty acid content of aged rice are significantly reduced during storage $(\mathrm{P}<\mathbf{0 . 0 5})$, while the nutritional value and content of essential amino acids do not differ from those of fresh brown rice $(\mathrm{P}>0.05)$. A total of five hundred 1-day-old broilers (Ross 308) were evenly divided by gender and randomly allocated into 5 groups (with 4 replicates of 25 birds), including: 1) control (corn-soybean meal), 2) $25 \%$ of corn replaced with $25 \%$ of ABR (ABR 25), 3) 50\% of corn replaced with 50\% of ABR (ABR 50), 4) 75\% of corn replaced with 75\% of ABR (ABR 75), 5) 100\% of ABR replaced with yellow corn (ABR 100), respectively, in order to evaluate growth performance as well as intestinal microflora population of broilers fed ABR. The diets were formulated to contain similar levels of the main nutrient requirements of broilers. The results indicated that the replacement of $A B R$ for corn in feed had no significant impact on the growth traits of broilers $(\mathrm{P}>\mathbf{0 . 0 5})$. The $\mathrm{pH}$ value of ileal digesta decreased as the replacement of $A B R$ increased at the age of 21 days $(P<0.05)$. The volatile fatty acids of ileal digesta of the ABR 75 and ABR 100 groups were significantly lower than those of the control group at the age of 21 days $(P<0.05)$, but not caecum. There was no difference with lactic acid bacteria and coliform counts in ileum and caecum, respectively, of broilers among the groups during the entire feeding period $(P>0.05)$. In conclusion, this study found that ABR may replace $100 \%$ of yellow corn and did not influence growth performance of broilers, thus providing an alternative for the use of stored rice in broiler diets.
\end{abstract}

Key words: aged brown rice, grain quality, performance, microflora, broilers

\footnotetext{
*The authors would like to thank the Council of Agriculture of Taiwan (101AS -2.1.4-AD -U1) for financially supporting this study.
} 
Corn is a principal energy source among cereals in poultry diets worldwide. For the last one and half decades, corn/maize production for fuel and poultry industries has been expanding, resulting in higher cost of corn and limiting its utilization in the feed industry (Vicente et al., 2008; Czech et al., 2014). It is necessary to seek lower cost by finding alternative energy sources for corn in poultry diets.

Rice (Oryza sativa) is a staple food of two-thirds of the global population, as well as approximately $90 \%$ of the annual production in Asia for more than 550 million people. It is the staple food of the eastern diet with a safe supply volume, as each country has a stock balance for emergency use (Czech et al., 2014). Regarding the old rice collected during storage, as the enzyme or photochemical reaction gradually decomposes macromolecular substances (e.g. carbohydrates, proteins and lipids), it produces a micromolecular compound with the acid group (e.g. organic acids, amino acids and fatty acids); thus, the granulation gradually becomes acidic. Moreover, the oxidized fat or free fatty acids produce hydroperoxide and carbonyl compounds, accelerating the change in the properties of storage protein, and influencing rice grain quality (Chen and Chen, 2003). Generally, the quality difference between fresh rice and aged rice could be judged by appearance, as aged rice often has lower transparency, yellowing and loss of gloss. Tamaki et al. (1993) pointed out that, in terms of standing storage, the physical and chemical properties of rice, including germination ratio, $\mathrm{pH}$ value and whiteness deteriorate after two years of storage. Therefore, when fresh rice has been stored in a general granary at normal temperatures for three years, it is no longer edible, and must serve other purposes.

In the rice grinding process, brown rice has better nutrient content than polished rice does, as the protein, fat and mineral substances mostly exist in the outer layers of the rice grain; the inner layers contain a starch grain and a slight amount of protein (Vicente et al., 2008). Since rice is a potential energy source, broken rice has been used for feeding trials in laying hen diets, and has achieved similar efficiency in regard to the utilization of energy (Jadhao et al., 1999). In addition, brown rice is applied in raising pigs, and can replace yellow corn, even up to $100 \%$ (Piao et al., 2002). Moreover, the price of brown rice is relatively lower than corn by approximately two-thirds (Piao et al., 2002). However, the effect of aged brown rice (ABR) on the growth performance of broilers has not yet been evaluated. This study aims to discuss the physical properties and nutrient content of ABR, and its effect in the replacement of corn meal on the growth performance and intestinal microflora population of broilers. The intention is to reduce feed costs and provide an alternative opportunity for the application of stored rice.

\section{Material and methods}

\section{Physical and proximate analysis of fresh brown rice and aged brown rice}

In terms of the germination rate (\%) of fresh brown rice (FBR) and ABR, 400 seeds were randomly sampled, placed in a Petri dish with filter paper in order to maintain moisture, in a growth box at the constant temperature of $30^{\circ} \mathrm{C}$, and illu- 
minated for 12 hours per day for seven days. In terms of $\mathrm{pH}$ value measurement, the FBR and ABR were ground and mixed with Methyl Red and bromothymol in ethyl alcohol, then thoroughly vibrated and immersed. The samples were then measured by a $\mathrm{pH}$ meter (Toadkk HM-25G). In terms of whiteness value measurement, the samples were ground into polished rice, and placed in the sampling case of the whiteness tester (Kett C-300). The fatty acid content $(\mathrm{mg} / \mathrm{g}$ ) was analysed using a taste analyser (Kett AN-800). In terms of proximate analysis, the dry matter, ash, crude protein and amino acid contents were analysed using AOAC (1998). The total starch, non-resistant starch and resistant starch were measured by a commercial starch analysis kit (Megazyme).

\section{Scanning electron microscopy observation}

The FBR and ABR were washed with distilled water and ethanol (100\%), and then dried at $50^{\circ} \mathrm{C}$. The dried samples were subjected to scanning electron microscopy (Bausch and Lomb Ltd. Nono lab 2100), as described by Lee et al. (2011).

\section{Animals and experimental design}

The experiment was conducted at the National Chung-Hsing University, and the experimental protocol for animal use was approved by the Animal Care and Use Committee. A total of five hundred 1-day-old broilers (Ross 308) were evenly divided by gender and randomly allocated into 5 groups: 1) control (corn-soybean meal), 2) $25 \%$ of corn replaced with $25 \%$ of ABR (ABR 25), 3) $50 \%$ of corn replaced with $50 \%$ of ABR (ABR 50), 4) $75 \%$ of corn replaced with $75 \%$ of ABR (ABR 75) and 5) $100 \%$ of ABR replaced with corn (ABR 100), as shown in Tables 1 and 2, respectively. For each treatment, 4 replicates were conducted ( 2 pens for males and 2 pens for females), and 25 broilers were assigned to each experimental pen. For the entire experimental period ( 5 weeks), all the diets were formulated to meet the requirements suggested by the NRC (1994). This study was divided into grower (0 to 21 days) and finisher periods (22 to 35 days), and diets in mash form and water were provided ad libitum. On days 21 and 35, the performance of the broilers was assessed by measuring the feed intake and body weight (BW) of the chicks, and the BW gain and feed conversion ratio $(\mathrm{F} / \mathrm{G})$ were recorded. On the same day, 8 chicks from each treatment ( 2 chickens per pen) were randomly selected and euthanized to determine the $\mathrm{pH}, \mathrm{VFA}$ value, and microbial assay of ileum and caecum content.

\section{The $\mathrm{pH}$ and VFA values of intestinal contents}

In terms of the $\mathrm{pH}$ value of chicken ileal digesta, $0.2 \mathrm{~g}$ content was uniformly mixed with $0.8 \mathrm{~mL}$ sterilized $\mathrm{PBS}$; the $\mathrm{pH}$ value was then directly measured using the glass electrode of a portable $\mathrm{pH}$ meter (Sentex TS-1, Taiwan). Regarding VFA analysis, the ileum and caeca contents individually, as well as double volume of the sulfuric acid solution of distilled water and oversaturated magnesium sulfate were sealed and fully vibrated, and then centrifuged at $4^{\circ} \mathrm{C}$ overnight. The distillate was collected, and phenolphthalein was used as the indicator. The $\mathrm{NaOH}$ was titrated until the indicator became pink, and the titration value was recorded in order to calculate the total VFA content (Parker, 1976). 
Table 1. Composition $(\mathrm{g} / \mathrm{kg})$ and calculated analysis of $\operatorname{diets}^{1}(0-21$ days $)$

\begin{tabular}{|c|c|c|c|c|c|}
\hline & $\mathrm{C} 100$ & ABR 25 & ABR 50 & ABR 75 & ABR 100 \\
\hline Corn & 470.0 & 352.5 & 235.0 & 117.5 & 0.0 \\
\hline Aged brown rice & 0.0 & 117.5 & 235.0 & 352.5 & 470.0 \\
\hline Soybean meal, CP44\% & 110.0 & 110.0 & 110.0 & 110.0 & 110.0 \\
\hline Full fat soybean meal & 316.0 & 316.0 & 316.0 & 316.0 & 316.0 \\
\hline Fish meal, CP60\% & 50.0 & 50.0 & 50.0 & 50.0 & 50.0 \\
\hline Soybean oil & 21.05 & 22.10 & 22.15 & 22.20 & 24.25 \\
\hline Dicalcium phosphorus & 12.49 & 11.58 & 11.75 & 11.71 & 10.58 \\
\hline Limestone & 10.63 & 10.99 & 10.78 & 11.07 & 11.36 \\
\hline Methionine & 1.53 & 1.51 & 1.48 & 1.46 & 1.43 \\
\hline Lysine & 2.31 & 1.82 & 1.84 & 1.56 & 0.38 \\
\hline Choline chloride $(50 \%)$ & 1.0 & 1.0 & 1.0 & 1.0 & 1.0 \\
\hline Mineral peimix ${ }^{2}$ & 1.0 & 1.0 & 1.0 & 1.0 & 1.0 \\
\hline Vitamin premix ${ }^{3}$ & 1.0 & 1.0 & 1.0 & 1.0 & 1.0 \\
\hline Salt & 3.0 & 3.0 & 3.0 & 3.0 & 3.0 \\
\hline Total & 1000 & 1000 & 1000 & 1000 & 1000 \\
\hline \multicolumn{6}{|l|}{ Calculated value } \\
\hline dry matter $(\%)$ & 88.95 & 89.30 & 89.65 & 90.00 & 90.36 \\
\hline crude protein $(\%)$ & 23.00 & 23.00 & 23.05 & 23.07 & 23.00 \\
\hline crude fat $(\%)$ & 9.79 & 9.60 & 9.31 & 9.02 & 8.93 \\
\hline $\mathrm{ME}(\mathrm{kcal} / \mathrm{kg})$ & 3125 & 3133 & 3135 & 3136 & 3149 \\
\hline calcium $(\%)$ & 1.04 & 1.04 & 1.04 & 1.05 & 1.04 \\
\hline total phosphorus (\%) & 0.79 & 0.77 & 0.77 & 0.76 & 0.74 \\
\hline available phosphorus (\%) & 0.51 & 0.50 & 0.51 & 0.52 & 0.50 \\
\hline lysine $(\%)$ & 1.51 & 1.48 & 1.49 & 1.48 & 1.39 \\
\hline methionine $(\%)$ & 0.55 & 0.55 & 0.55 & 0.55 & 0.55 \\
\hline cysteine $(\%)$ & 0.36 & 0.35 & 0.35 & 0.34 & 0.33 \\
\hline sulphur amino acids (\%) & 0.91 & 0.90 & 0.90 & 0.89 & 0.88 \\
\hline threonine $(\%)$ & 0.90 & 0.89 & 0.89 & 0.89 & 0.89 \\
\hline tryptophan (\%) & 0.28 & 0.28 & 0.28 & 0.29 & 0.29 \\
\hline $\mathrm{Cl}(\%)$ & 0.24 & 0.23 & 0.23 & 0.22 & 0.22 \\
\hline $\mathrm{Na}(\%)$ & 0.18 & 0.18 & 0.18 & 0.17 & 0.17 \\
\hline K (\%) & 0.95 & 0.91 & 0.87 & 0.84 & 0.80 \\
\hline
\end{tabular}

${ }^{1} \mathrm{C} 100$ : control (corn-soybean meal); ABR 25: $25 \%$ of corn replaced with $25 \%$ of ABR (aged brown rice); ABR 50: $50 \%$ of corn replaced with 50\% of ABR; ABR 75: $75 \%$ of corn replaced with $75 \%$ of ABR; ABR 100 : $100 \%$ of ABR groups, respectively.

${ }^{2} \mathrm{Mineral}$ (premix content per kg diet): $\mathrm{Co}\left(\mathrm{CoCO}_{3}\right), 0.255 \mathrm{mg} ; \mathrm{Cu}\left(\mathrm{CuSO}_{4} \cdot 5 \mathrm{H}_{2} \mathrm{O}\right), 10.8 \mathrm{mg} ; \mathrm{Fe}\left(\mathrm{FeSO}_{4} \cdot \mathrm{H}_{2} \mathrm{O}\right)$, $90 \mathrm{mg} ; \mathrm{Mn}\left(\mathrm{MnSO}_{4} \cdot \mathrm{H}_{2} \mathrm{O}\right), 90 \mathrm{mg} ; \mathrm{Zn}(\mathrm{ZnO}), 68.4 \mathrm{mg} ; \mathrm{Se}\left(\mathrm{Na}_{2} \mathrm{SeO}_{3}\right), 0.18 \mathrm{mg}$.

${ }^{3}$ Vitamin (premix content per kg diet): vit. A, $15000 \mathrm{IU}$; vit. $\mathrm{D}_{3}$, $3000 \mathrm{IU}$; vit. E, $30 \mathrm{mg}$; vit. $\mathrm{K}_{3}$, $4 \mathrm{mg}$; thiamine, $3 \mathrm{mg}$; riboflavin, $8 \mathrm{mg}$; pyridoxine, $5 \mathrm{mg}$; vit. $\mathrm{B}_{12}, 25 \mathrm{mcg}$; Ca-pantothenate, $19 \mathrm{mg}$; niacin, $50 \mathrm{mg}$; folic acid, $1.5 \mathrm{mg}$; biotin, $60 \mathrm{mcg}$. 
Table 2. Composition $(\mathrm{g} / \mathrm{kg})$ and calculated analysis of $\operatorname{diets}^{1}$ (22-35 days)

\begin{tabular}{|c|c|c|c|c|c|}
\hline & $\mathrm{C} 100$ & ABR 25 & ABR 50 & ABR 75 & ABR 100 \\
\hline Corn & 470.12 & 352.50 & 235.00 & 117.50 & 0.0 \\
\hline Aged brown rice & 0.0 & 117.50 & 235.00 & 352.50 & 469.99 \\
\hline Soybean meal, CP44\% & 104.06 & 104.03 & 104.03 & 104.03 & 104.03 \\
\hline Full fat soybean meal & 353.19 & 353.09 & 353.09 & 353.09 & 353.09 \\
\hline Fish meal, CP60\% & 4.0 & 4.0 & 4.0 & 4.0 & 4.0 \\
\hline Soybean oil & 31.90 & 31.71 & 31.92 & 32.01 & 32.01 \\
\hline Dicalcium phosphorus & 15.33 & 14.99 & 14.65 & 14.72 & 14.93 \\
\hline Limestone & 11.70 & 12.53 & 12.72 & 12.62 & 12.46 \\
\hline Methionine & 2.74 & 2.80 & 2.86 & 2.92 & 2.98 \\
\hline Lysine & 0.46 & 0.34 & 0.22 & 0.10 & 0.00 \\
\hline Choline chloride $(50 \%)$ & 1.0 & 1.0 & 1.0 & 1.0 & 1.0 \\
\hline Mineral premix ${ }^{2}$ & 1.0 & 1.0 & 1.0 & 1.0 & 1.0 \\
\hline Vitamin premix ${ }^{3}$ & 1.0 & 1.0 & 1.0 & 1.0 & 1.0 \\
\hline Salt & 3.5 & 3.5 & 3.5 & 3.5 & 3.5 \\
\hline Total & 1000 & 1000 & 1000 & 1000 & 1000 \\
\hline \multicolumn{6}{|l|}{ Calculated value } \\
\hline dry matter (\%) & 89.08 & 89.44 & 89.79 & 90.14 & 90.49 \\
\hline crude protein $(\%)$ & 21.00 & 21.00 & 21.00 & 21.00 & 21.00 \\
\hline crude fat $(\%)$ & 11.3 & 10.99 & 10.72 & 10.43 & 10.14 \\
\hline $\mathrm{ME}(\mathrm{kcal} / \mathrm{kg})$ & 3319 & 3311 & 3307 & 3303 & 3300 \\
\hline calcium $(\%)$ & 0.84 & 0.86 & 0.86 & 0.86 & 0.86 \\
\hline total phosphorus $(\%)$ & 0.70 & 0.69 & 0.68 & 0.68 & 0.68 \\
\hline available phosphorus (\%) & 0.41 & 0.41 & 0.41 & 0.42 & 0.43 \\
\hline lysine $(\%)$ & 1.22 & 1.22 & 1.22 & 1.22 & 1.22 \\
\hline methionine $(\%)$ & 0.60 & 0.61 & 0.62 & 0.63 & 0.64 \\
\hline cysteine $(\%)$ & 0.35 & 0.34 & 0.33 & 0.32 & 0.31 \\
\hline sulphur amino acid (\%) & 0.95 & 0.95 & 0.95 & 0.95 & 0.95 \\
\hline threonine $(\%)$ & 0.82 & 0.82 & 0.81 & 0.81 & 0.81 \\
\hline tryptophan (\%) & 0.26 & 0.26 & 0.27 & 0.27 & 0.28 \\
\hline $\mathrm{Cl}(\%)$ & 0.22 & 0.21 & 0.21 & 0.20 & 0.20 \\
\hline $\mathrm{Na}(\%)$ & 0.17 & 0.17 & 0.17 & 0.17 & 0.17 \\
\hline $\mathrm{K}(\%)$ & 0.97 & 0.93 & 0.89 & 0.85 & 0.81 \\
\hline
\end{tabular}

${ }^{1}$ C100: control (corn-soybean meal); ABR 25: 25\% of corn replaced with 25\% of ABR (aged brown rice); ABR 50: $50 \%$ of corn replaced with $50 \%$ of ABR; ABR 75: $75 \%$ of corn replaced with $75 \%$ of ABR; ABR 100: $100 \%$ of ABR groups, respectively.

${ }^{2} \mathrm{Mineral}$ (premix content per kg diet): $\mathrm{Co}\left(\mathrm{CoCO}_{3}\right), 0.255 \mathrm{mg} ; \mathrm{Cu}\left(\mathrm{CuSO}_{4} \cdot 5 \mathrm{H}_{2} \mathrm{O}\right), 10.8 \mathrm{mg} ; \mathrm{Fe}\left(\mathrm{FeSO}_{4} \cdot \mathrm{H}_{2} \mathrm{O}\right)$, $90 \mathrm{mg} ; \mathrm{Mn}\left(\mathrm{MnSO}_{4} \cdot \mathrm{H}_{2} \mathrm{O}\right), 90 \mathrm{mg} ; \mathrm{Zn}(\mathrm{ZnO}), 68.4 \mathrm{mg} ; \mathrm{Se}\left(\mathrm{Na}_{2} \mathrm{SeO}_{3}\right), 0.18 \mathrm{mg}$.

${ }^{3}$ Vitamin (premix content per kg diet): vit. A, $15000 \mathrm{IU}$; vit. $\mathrm{D}_{3}$, $3000 \mathrm{IU}$; vit. E, $30 \mathrm{mg}$; vit. $\mathrm{K}_{3}, 4 \mathrm{mg}$; thiamine, $3 \mathrm{mg}$; riboflavin, $8 \mathrm{mg}$; pyridoxine, $5 \mathrm{mg}$; vit. $\mathrm{B}_{12}, 25 \mathrm{mcg}$; Ca-pantothenate, $19 \mathrm{mg}$; niacin, $50 \mathrm{mg}$; folic acid, $1.5 \mathrm{mg}$; biotin, $60 \mathrm{mcg}$. 


\section{Intestinal microflora assay}

The ileum and caeca contents were appropriately diluted with PBS for assay. The Lactobaclilli and Coliform count were cultured and determined by Man Rogosa Sharpe (MRS) (Difco Co., Detroit, MI, USA) and coliform agar (Merck KGaA, Germany) (Lee et al., 2010).

\section{Statistical analysis}

All results were analysed using the Statistical Analysis System software package (version 6.1; SAS, 1999). The least square mean test was used to detect the differences between treatments. The differences were considered as significant at $\mathrm{P}<0.05$.

\section{Results}

\section{Physical properties and proximate analysis of rice}

The physical properties and proximate analysis of FBR and ABR are shown in Table 3 . The indices of germination rate, $\mathrm{pH}$ value, whiteness value, moisture and fatty acid contents decreased significantly $(\mathrm{P}<0.05)$ for ABR compared to FBR; ABR hardly germinated. However, there was no significant change in the dry matter or ash contents of FBR and ABR. The total starch content, crude protein, resistant starch and essential amino acid content were similar between the grains $(\mathrm{P}>0.05)$. The scanning electron micrographs of FBR and ABR starch granules morphology are shown in Figure 1. The starch granules were similar between rice types, and size showed a polygonal sphere of 2 to $10 \mu \mathrm{m}$ in diameter.

(A)

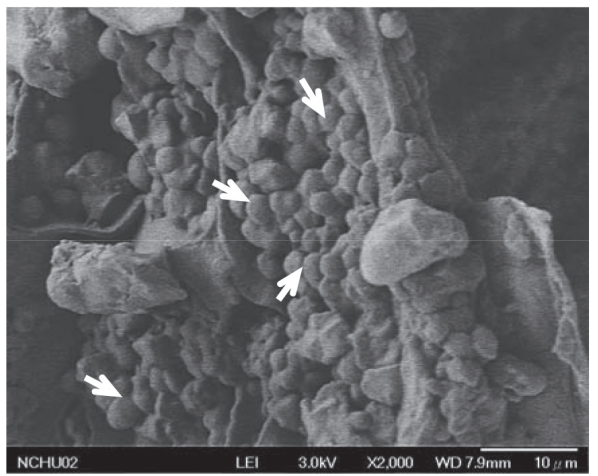

(B)

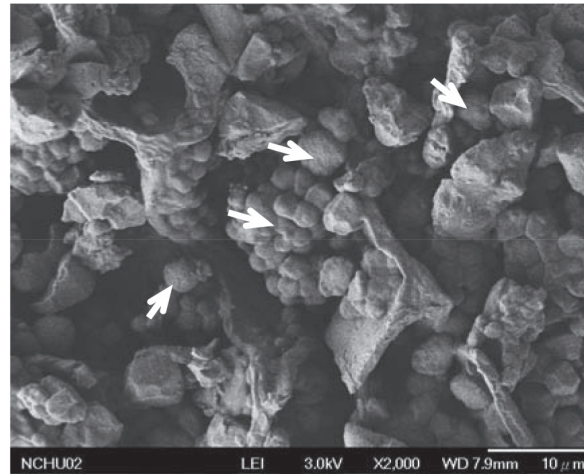

Figure 1. Scanning electron micrographs of fresh brown rice (A) and aged brown rice (B) starch granules. Locations of starch granules are indicated by arrows

\section{Birds' growth performance}

The growth performance of the broilers is shown in Table 4. The replacement of $\mathrm{ABR}$ for different proportions of yellow corn in feed had no significant impact on the 
body weight or body weight gain of broilers during 0-35 days $(\mathrm{P}>0.05)$. Feed intake increased with the replacement of ABR during 0-21 days; however, feed conversion (intake/gain) did not change during the feeding period ( $\mathrm{P}>0.05)$. In 0 to 35 days, feed conversion was approximately $1.56-1.57$ in all groups. Therefore, ABR may replace $100 \%$ of yellow corn; it will not influence the growth performance of broilers.

Table 3. Physical properties and proximate analysis of fresh brown rice and aged brown rice

\begin{tabular}{|c|c|c|}
\hline Item & Fresh brown rice $^{1}$ & Aged brown rice \\
\hline Germination (\%) & $87.8 \mathrm{a}$ & $0.3 \mathrm{~b}$ \\
\hline $\mathrm{pH}$ value & $6.44 \mathrm{a}$ & $5.79 \mathrm{~b}$ \\
\hline Whiteness value & $47.2 \mathrm{a}$ & $40.6 \mathrm{~b}$ \\
\hline Dry matter $(\%)$ & 88.75 & 88.61 \\
\hline Crude protein $(\%)$ & 6.61 & 6.39 \\
\hline Ash (\%) & 1.42 & 1.55 \\
\hline Fatty acid content $(\%)$ & $2.83 \mathrm{a}$ & $2.60 \mathrm{~b}$ \\
\hline Resistant starch (\%) & 0.12 & 0.15 \\
\hline Non-resistant starch (\%) & 77.8 & 77.7 \\
\hline Total starch (\%) & 78.2 & 77.5 \\
\hline Metabolizable energy $(\mathrm{kcal} / \mathrm{kg})^{2}$ & ND & 3350.0 \\
\hline \multicolumn{3}{|l|}{ Amino acids (\%) } \\
\hline threonine & 0.28 & 0.26 \\
\hline cysteine & 0.11 & 0.13 \\
\hline valine & 0.42 & 0.39 \\
\hline methionine & 0.16 & 0.15 \\
\hline isoleucine & 0.27 & 0.26 \\
\hline leucine & 0.62 & 0.64 \\
\hline phenylalanine & 0.39 & 0.34 \\
\hline lysine & 0.31 & 0.27 \\
\hline histidine & 0.19 & 0.17 \\
\hline arginine & 0.67 & 0.60 \\
\hline
\end{tabular}

${ }^{1}$ Each value is the mean of four samples.

${ }^{2}$ The value was referred from the Livestock Research Institute (2011). Tables of Feed Compositions, 3rd ed. Council of Agriculture, Executive Yuan Press, Taiwan. ND: no determination.

$\mathrm{a}, \mathrm{b}-$ means within the same row without the same letters differ significantly $(\mathrm{P}<0.05)$.

\section{The $\mathbf{p H}$ value and total VFA content of intestinal digesta}

The $\mathrm{pH}$ value and total VFA content of intestinal digesta are shown in Tables 5 and 6 . The groups where corn was replaced with $75 \%$ and $100 \%$ ABR had the lowest $\mathrm{pH}$ values in ileum digesta of 21-day-old broilers, which is significantly different from the control group $(\mathrm{P}<0.05)$. The 21 -day ileum VFA production of the groups 
where corn was replaced with $75 \%$ and $100 \%$ ABR were significantly lower than that of the control group $(\mathrm{P}<0.05)$. There was no significant difference in the various treatment rooms during the entire feeding period $(\mathrm{P}>0.05)$.

Table 4. Effect of aged brown rice replaced with corn on the growth performance of broiler chicks

\begin{tabular}{|c|c|c|c|c|c|c|}
\hline \multirow{2}{*}{ Item } & \multicolumn{5}{|c|}{ Treatments $^{1}$} & \multirow{2}{*}{ SEM } \\
\hline & $\mathrm{C} 100$ & ABR 25 & ABR 50 & ABR 75 & ABR 100 & \\
\hline \multicolumn{7}{|l|}{ Body weight (g/bird) } \\
\hline 21 day & 858 & 868 & 856 & 875 & 877 & 25.6 \\
\hline 35 day & 1984 & 1955 & 2001 & 1928 & 2009 & 66.3 \\
\hline \multicolumn{7}{|c|}{ Body weight gain (g/bird) } \\
\hline $0-21$ days & 820 & 830 & 818 & 837 & 838 & 25.6 \\
\hline $22-35$ days & 1128 & 1070 & 1134 & 1034 & 1132 & 50.2 \\
\hline $0-35$ days & 1946 & 1917 & 1964 & 1890 & 1970 & 66.3 \\
\hline \multicolumn{7}{|l|}{ Feed intake $^{2}(\mathrm{~g} / \mathrm{bird})$} \\
\hline $0-21$ days & $1047 \mathrm{~b}$ & $1081 \mathrm{ab}$ & $1097 \mathrm{ab}$ & $1129 \mathrm{a}$ & 1112 a & 18.74 \\
\hline $22-35$ days & 2000 & 1898 & 1974 & 1821 & 1951 & 64.7 \\
\hline $0-35$ days & 3047 & 2979 & 3071 & 2950 & 3063 & 75.2 \\
\hline \multicolumn{7}{|c|}{ Feed conversion (intake/gain) } \\
\hline $0-21$ days & 1.29 & 1.31 & 1.35 & 1.36 & 1.34 & 0.035 \\
\hline $22-35$ days & 1.78 & 1.78 & 1.75 & 1.77 & 1.74 & 0.034 \\
\hline $0-35$ days & 1.57 & 1.56 & 1.57 & 1.56 & 1.57 & 0.022 \\
\hline
\end{tabular}

${ }^{1} \mathrm{C} 100$ : control (corn-soybean meal); ABR 25: $25 \%$ of corn replaced with $25 \%$ of ABR (aged brown rice); ABR 50: $50 \%$ of corn replaced with $50 \%$ of ABR; ABR 75: $75 \%$ of corn replaced with $75 \%$ of ABR; ABR 100 : $100 \%$ of ABR groups, respectively.

${ }^{2}$ Results are given as the means of 4 pens for 25 birds in each pen.

$\mathrm{a}, \mathrm{b}-$ means within the same row without the same letters differ significantly $(\mathrm{P}<0.05)$.

Table 5. Effect of aged brown rice replaced with corn on the $\mathrm{pH}$ value of ileum contents of broiler chicks

\begin{tabular}{|c|c|c|c|c|c|c|}
\hline \multirow{2}{*}{ Item } & \multicolumn{5}{|c|}{ Treatments $^{1}$} & \multirow{2}{*}{ SEM } \\
\hline & $\mathrm{C} 100$ & ABR 25 & ABR 50 & ABR 75 & ABR 100 & \\
\hline \multicolumn{7}{|l|}{21 day } \\
\hline Ileum $^{2}$ & $6.94 \mathrm{a}$ & $6.12 \mathrm{ab}$ & $6.57 \mathrm{a}$ & $5.68 \mathrm{~b}$ & $5.67 \mathrm{~b}$ & 0.266 \\
\hline \multicolumn{7}{|l|}{35 day } \\
\hline Ileum $^{2}$ & 7.85 & 8.28 & 8.59 & 7.18 & 7.64 & 0.527 \\
\hline
\end{tabular}

${ }^{1} \mathrm{C} 100$ : control (corn-soybean meal); ABR 25: $25 \%$ of corn replaced with $25 \%$ of ABR (aged brown rice); ABR 50: $50 \%$ of corn replaced with 50\% of ABR; ABR 75: $75 \%$ of corn replaced with $75 \%$ of ABR; ABR 100 : $100 \%$ of ABR groups, respectively.

${ }^{2}$ Each value is the mean of eight samples ( 2 samples from each of four replicates).

$\mathrm{a}, \mathrm{b}-$ means within the same row without the same letters differ significantly $(\mathrm{P}<0.05)$. 
Table 6. Effect of aged brown rice replaced with corn on the VFA value of caecum contents of broiler chicks

\begin{tabular}{|c|c|c|c|c|c|c|}
\hline \multirow{2}{*}{ Item } & \multicolumn{5}{|c|}{ Treatments $^{1}$} & \multirow{2}{*}{ SEM } \\
\hline & $\mathrm{C} 100$ & ABR 25 & ABR 50 & ABR 75 & ABR 100 & \\
\hline \multicolumn{7}{|l|}{21 day } \\
\hline Ileum $^{2}(\mu$ mole/g) & $40.3 \mathrm{a}$ & $38.4 \mathrm{ab}$ & $34.4 \mathrm{ab}$ & $29.7 \mathrm{~b}$ & $30.6 \mathrm{~b}$ & 2.71 \\
\hline Caecum $^{2}(\mu \mathrm{mole} / \mathrm{g})$ & 164 & 185 & 201 & 184 & 182 & 22.9 \\
\hline \multicolumn{7}{|l|}{35 day } \\
\hline Ileum $^{2}(\mu$ mole/g) & 18.5 & 28.0 & 28.6 & 25.8 & 19.1 & 4.36 \\
\hline Caecum $^{2}(\mu \mathrm{mole} / \mathrm{g})$ & 145 & 139 & 138 & 154 & 139 & 7.68 \\
\hline
\end{tabular}

${ }^{1} \mathrm{C} 100$ : control (corn-soybean meal); ABR 25: $25 \%$ of corn replaced with $25 \%$ of ABR (aged brown rice); ABR 50: $50 \%$ of corn replaced with 50\% of ABR; ABR 75: $75 \%$ of corn replaced with $75 \%$ of ABR; ABR 100: $100 \%$ of ABR groups, respectively.

${ }^{2}$ Each value is the mean of eight samples ( 2 samples from each of four replicates).

$\mathrm{a}, \mathrm{b}-$ means within the same row without the same letters differ significantly $(\mathrm{P}<0.05)$.

\section{Intestinal microflora}

The intestinal microflora of the broilers is shown in Table 7. In terms of intestinal microflora when replacing ABR for corn in broiler feed, the results showed that there was no significant difference in lactic acid bacteria and coliform in the ileum and caeca contents of broilers in the various groups during the entire period.

Table 7. Effect of aged brown rice replaced with corn on the intestinal microflora of broiler chicks

\begin{tabular}{|c|c|c|c|c|c|c|}
\hline \multirow{2}{*}{ Item } & \multicolumn{5}{|c|}{ Treatments $^{1}$} & \multirow{2}{*}{ SEM } \\
\hline & $\mathrm{C} 100$ & ABR 25 & ABR 50 & ABR 75 & ABR 100 & \\
\hline \multicolumn{7}{|l|}{21 day } \\
\hline \multicolumn{7}{|l|}{ Ileum $^{2}$} \\
\hline Lactobacillus (log CFU/g) & 8.58 & 8.72 & 8.31 & 8.53 & 8.48 & 0.221 \\
\hline Coliform (log CFU/g) & 6.16 & 6.51 & 6.35 & 6.13 & 6.08 & 0.163 \\
\hline \multicolumn{7}{|l|}{ Caecum $^{2}$} \\
\hline Lactobacillus (log CFU/g) & 9.26 & 8.85 & 8.93 & 8.88 & 8.76 & 0.208 \\
\hline Coliform (log CFU/g) & 8.45 & 8.65 & 8.14 & 8.23 & 8.15 & 0.179 \\
\hline \multicolumn{7}{|l|}{35 day } \\
\hline \multicolumn{7}{|l|}{ Ileum $^{2}$} \\
\hline Lactobacillus (log CFU/g) & 8.36 & 8.38 & 7.87 & 8.71 & 8.42 & 0.269 \\
\hline Coliform (log CFU/g) & 6.44 & 6.91 & 6.00 & 6.74 & 6.91 & 0.186 \\
\hline \multicolumn{7}{|l|}{ Caecum $^{2}$} \\
\hline Lactobacillus & 8.24 & 8.44 & 8.60 & 8.76 & 8.78 & 0.338 \\
\hline Coliform & 7.86 & 8.88 & 7.90 & 8.24 & 8.01 & 0.324 \\
\hline
\end{tabular}

${ }^{1}$ C100: control (corn-soybean meal); ABR 25: 25\% of corn replaced with 25\% of ABR (aged brown rice); ABR 50: $50 \%$ of corn replaced with 50\% of ABR; ABR 75: $75 \%$ of corn replaced with $75 \%$ of ABR; ABR 100: $100 \%$ of ABR groups, respectively.

${ }^{2}$ Each value is the mean of eight samples (2 samples from each of four replicates). 


\section{Discussion}

The difference between FBR and ABR could be directly observed in the appearance, as ABR often has lower transparency, yellowing and loss of gloss, which is easily observed by eye or inspected by a whiteness tester. Using the biochemical analysis procedure to assay the freshness of rice indicated that the $\mathrm{pH}$ value of rice gradually decreases during the storage process. The first cause of a decreased $\mathrm{pH}$ value is when starch is decomposed into monosaccharide; the carbohydrate decomposition and TCA circulation generate organic acid or fat for oxidation causes rancidification (Lii et al., 1999; Chen and Chen, 2003). Tamaki et al. (1993) indicated that in storage, rice texture only deteriorated severely during the first two years of storage, and then only changed slightly. In terms of change in the chemical composition of grain during storage, lipids change the fastest. Therefore, the activity of public grain seeds decreased rapidly during three-year storage. The other physical, chemical properties and proximate analysis changed slightly, and the amino acid composition of ABR was similar to that of FBR in current, and preliminarily evaluated as feedstuff rice for livestock.

If the ration has a high content of non-starch polysaccharides, the digestive energy intake of baby pigs will be directly reduced. The starch content is higher in rice than in corn, and the amylose proportion as well as non-starch polysaccharide content are lower than in corn; moreover, the size is smaller than that of corn. Therefore, rice has better performance than corn (Mateos et al., 2007; Vicente et al., 2008). Piao et al. (2002) evaluated the use of Chinese brown rice as an alternative energy source in pig feed, and showed that the nutrient digestibility was not significantly different in most nutrients. Brown rice appeared to be a good alternative energy source that can replace yellow corn up to $100 \%$ in growing pigs. This is consistent with the results of current studies on broilers with ABR. Li et al. (2004) increased the utilization rate of Chinese stored brown rice in pig feed, and found that neither extrusion nor enzyme supplementations are necessary for stored brown rice to be used in pig diets. A similar study also showed that brown rice is better than corn in apparent ileal digestibility, as well as in the metabolizable rate of amino acids and gross energy (Li et al., 2002; Zhang et al., 2002).

González-Alvarado et al. (2008) indicated that there is no difference between a polished broken rice diet and a corn diet; the relative weights of proventriculus and gizzard of broilers are lower than a corn diet, and the intestinal digesta $\mathrm{pH}$ is significantly reduced, which is identical to the results of this study. Moreover, supplementing oat hull stimulates the development of the upper GI, as the inclusion of hulls in a rice diet is regarded as a stimulant to the development of the upper part of the GIT and optimal functioning of the gizzard in young broilers.

Intestinal microorganisms can ferment the polysaccharides, cellulose and hemicellulose of feed (Cummings and Macfarlane, 1991). The VFA, such as acetic acid, propionic acid and butyric acid, are the primary product of the fermentation of carbohydrates and protein in the intestinal tract (Macfarlane and Gibson, 1995). More than $95 \%$ of the VFA produced by intestinal microorganisms can be absorbed and metabolized by the host (Cummings, 1995). In in vitro testing, VFA at appropriate 
concentrations can reduce the bacterial count of E. coli (Cherrington et al., 1990), as VFA inhibit the growth of gram negative bacteria in its undissociated form (Thompson and Hinton, 1997). The VFA composition is influenced by the change in intestinal microflora: when the number of lactic acid bacteria in the intestinal tract increases, the VFA concentration increases; the output represents the strain fermentation efficiency (Olivares et al., 2006; Leeson et al., 2005). The ileal VFA of 21-day-old broilers decreases significantly as the replacement of old rice increases, which may be because the old rice has a lower content of non-starch polysaccharides than corn (Mateos et al., 2007; Vicente et al., 2008).

The $\mathrm{pH}$ value of the alimentary tract influences the inhibiting ability of VFA for microorganisms. Van Immerseel et al. (2003) indicated that when the $\mathrm{pH}$ value was 6 , the short chain fatty acid inhibited enteric pathogenic bacteria better than when the $\mathrm{pH}$ value was 7 . As short chain fatty acids mostly exist in an undissociated form in a subacid environment, more VFA enter the intestinal tract cells for bacteriostatic effect. The ileal $\mathrm{pH}$ at the age of 21 days is lower in this study, and is likely to have better inhibitory effect on Coliform bacteria. However, the produced VFA are lower, which neutralizes their capability. There is no difference in the caecal part at the age of 35 days in groups. The count of lactic acid bacteria in the intestinal tract at the age of 21 days is no different from that at the age of 35 days. This result is similar to a previous study, which indicated that the intestinal microflora of broilers develops stably in 2-3 weeks, and then the bacterial count does not fluctuate significantly (Snel et al., 2002). In conclusion, this study found that ABR may replace $100 \%$ of yellow corn and did not influence growth performance of broilers, thus providing an alternative for the use of stored rice in broiler diets. Therefore, the price relationship between corn and ABR may provide an excellent opportunity for the application of stored rice.

\section{Acknowledgements}

The authors would like to thank the Agriculture and Food Agency, Council of Agriculture, Executive Yuan, for allowing buying public grain materials; and the Council of Agriculture of Taiwan (101AS -2.1.4-AD -U1) for financially supporting this study. Thanks also go to Ms. Wen-Hsin Chang for her assistance to animal feeding, and to the Hualien District Agricultural Improvement Station for assisting with rice quality analysis.

\section{References}

AOAC (1998). Official methods of analysis (15th ed.). Association of Official Analytical Chemists. Washington. DC.

$\mathrm{C}$ h e $\mathrm{n}$ T.F., $\mathrm{C}$ h e n C.L. (2003). Analysing the freshness of intact rice grains by colour determination of peroxidase activity. J. Sci. Food Agric., 83: 1214-1218.

Cherringt on C.A., H in ton M., Ch o pra I. (1990). Effect of short-chain organic acids on macromolecular synthesis in Escherichia coli. J. Appl. Bacteriol., 68: 69-74

Cum mings J.H., M a c farlane G.T. (1991). A review: the control and consequences of bacterial fermentation in the human colon. J. Appl. Bacteriol., 70: 443-459. 
Czech A., Pastuszak J., Kusior G. (2014). Effects of increased content of animal protein in feed mixtures based on extruded rice on rearing performance and blood parameters of piglets. Ann. Anim. Sci., 14: 117-126.

González-A lvarado J.M., Ji méne z-Moreno E., Valencia D.G., Lázaro R., Mate o s G.G. (2008). Effects of fiber source and heat processing of the cereal on the development and $\mathrm{pH}$ of the gastrointestinal tract of broilers fed diets based on corn or rice. Poultry Sci., 87: 1779-1795.

J a dh a o S.B., Chandra mon i A.S., Tiw a r i C.M., Kh a n M.Y. (1999). Efficiency of utilisation of energy from maize- and broken rice based diets in old White Leghorn and Rhode Island Red laying hens. Br. Poultry Sci., 40: 275-283.

Lee T.T., Chang C.C., Juang R.S., Chen R.B, Yang S.Y., Chu L.W., Wang S.R., Wang C.S., Tseng T.H., Chen L.J., Yu B. (2010). Porcine lactoferrin expression in transgenic rice and its effects as a feed additive on early weaned piglets. J. Agric. Food Chem., 58: 5166-5173

L e e T.T., Hu ang Y.F., Chi ang C.C., Chung T.K., Chiou P.W.S., Yu B. (2011). Starch characteristics and their influences on in vitro and pig prececal starch digestion. J. Agric. Food Chem., 59: 7353-7359.

Le e s on S., N a m kung H., An to n gi o vann i M., L e e E.H. (2005). Effect of butyric acid on the performance and carcass yield of broiler chickens. Poultry Sci. 84: 1418-1422.

L i D.F., Z hang D.F., P i a X X.S., H a n I.K., Yang C.J., L i J.B., L e e J.H. (2002). Effects of replacing maize with Chinese brown rice on growth performance and apparent fecal digestibility of nutrients in weanling pigs. Asian-Aust. J. Anim. Sci., 15: 1191-1197.

L i J., L i D., Y in Y.L., P i a o X.S., H e J.H., Chen G.P., Sh u J.C. (2004). Performance, nutrient digestibility and intestinal disaccharidase activity of weaner/grower pigs given diets containing extruded Chinese stored brown rice with exogenous enzyme supplements. Anim. Sci., 79: 429-438.

L i i L.J., Wang C.Y., L u r H.S. (1999). A novel means of analyzing the soluble acidity of rice grains. Crop Sci., 39: 1160-1164.

M a c farla n e G.T., Gi b s o n G.R. (1995). Microbiological aspects of short chain fatty acid production in the large bowel. In: Physiological and Clinical Aspects of Short Chain Fatty Acid Metabolism. Cambridge University Press, Cambridge, pp. 119-132.

Mate os G.G., L opez E., L a t or re M.A., Vic en te B., L a z a ro R.P. (2007). The effect of inclusion of oat hulls in piglet diets based on raw or cooked rice and maize. Anim. Feed Sci. Technol., 135: $100-112$.

Olivares M., Díaz-Popero M.P., Gómez N., Sierra S., Lara-Villos la da F., Martín R., R odríg u e z J.M., X a u s J. (2006). Dietary deprivation of fermented foods causes a fall in innate immune response: Lactic acid bacteria can counteract the immunological effect of this deprivation. J. Dairy Res., 22: 1-7.

P a r k e r D.S. (1976). The measurement of production rates of volatile fatty acids in the caecum of the conscious rabbit. Br. J. Nutr., 36: 61-70.

P i a o X.S., L i D., H a n I.K., Che n Y., L e e J.H., Wang D.Y., Li J.B., Z hang D.F. (2002). Evaluation of Chinese brown rice as an alternative energy source. Asian-Aust. J. Anim. Sci., 15: 89-93.

Snel J.H., Harmsen J.M., ven de Wi elen P.W.J.J., Willi a m s B.A. (2002). Dietary strategies to influence the gastrointestinal microflora of young animals, and its potential to improve intestinal health. In: Nutrition and health of the gastrointestinal tract, Blok M.C. (ed.). Wageningen Academic Publishers, Wageningen, Netherlands, pp. 37-69.

Tamaki M., Tas hiro T., I s hi kaw a M., E b a t a M. (1993). Physico-ecological studies on quality formation of rice kernel: IV. Effect of storage on eating quality of rice. Jpn. J. Crop Sci., 62: $540-546$

Th o m p s o n J.L., H in t on M. (1997). Antibacterial activity of formic and propionic acids in the diet of hens on salmonellas in the crop. Br. Poultry Sci., 38: 59-63.

Van Immerse el F., De Buck J., Meulemans G., Pas mans F., Velge P., B ottreau E., Ha e s e brouck F., D u c a telle R. (2003). Invasion of Salmonella enteritidis in avian intestinal epithelial cells in vitro is influenced by short-chain fatty acids. Inter. J. Food Micro., 85: $237-248$.

Vicente B., Valencia D.G., Pérez-Serrano M., Lázaro R., Ma teos G.G. (2008). The effects of feeding rice in substitution of corn and the degree of starch gelatinization of rice on the 
digestibility of dietary components and productive performance of young pigs. J. Anim. Sci., 86: $119-126$.

Zhang D.F., Li D.F., Pia o X.S., Han I.K., Yang C.J., Da i J.G., Li J.B. (2002). Effects of replacing maize with brown rice or brown rice with enzyme on growth performance and nutrient digestibility in growing pigs. Asian-Aust. J. Anim. Sci., 15: 1334-1340.

Received: 4 III 2014

Accepted: 24 V 2014 